\title{
Safety Analysis of Landing-Type Lifting Pole with Double-Level Arms under Wind Load Function
}

\author{
J. Qin \\ China Electric Power Research Institute \\ Beijing, China \\ J. Su \\ Shenyang Sanyo Building Machinery Co., Ltd \\ Shenyang, China
}

\author{
K.F. Huang \\ Peking University \\ Beijing, China
}

\author{
H.S. Zhang \\ Harbin Institute of Technology \\ Harbin, China \\ J.M. Zhang \\ China Electric Power Research Institute \\ Beijing, China \\ D. $\mathrm{Ni}$ \\ China Electric Power Research Institute \\ Beijing, China
}

\begin{abstract}
According to design requirements for landing-type lifting pole with double-level arms, the working conditions of landing-type lifting pole with double-level arms are proposed under different wind pressures and wind directions, and the component stresses of several important standard sections of pole body are calculated under different load factors. For standard sections whose main chord members cannot meet strength and safety requirements, this thesis considered adding hawser cables, thus obtaining the stress results meeting design requirements. Relevant calculation methods can be taken as reference for lifting pole design.
\end{abstract} safety

Keywords-double-level arms; lifting pole; structural analysis;

\section{INTRODUCTION}

The landing-type lifting pole with double-level arms was developed from the construction tower crane[1]. The lifting pole is placed on the ground of iron tower center. For iron tower in transmission line which has the hollow structure and whose materials are distributed symmetrically about the pole body axle center during construction, the lifting pole is designed as the pattern with double arms[2], shown in Figure 1. Double hooks can lift objects in a balanced way within the ruled unbalanced moment difference. Besides the rated lifting capacity and rated lifting moment, the lifting pole still needs to control the lifting moment difference of double hooks automatically.

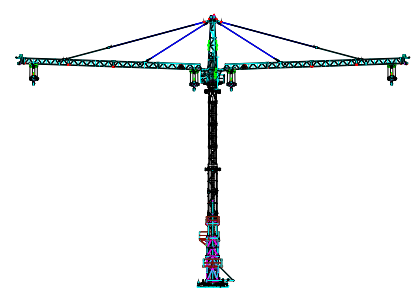

FIGURE I .SP80 - LANDING-TYPE LIFTING POLE WITH DOUBLELEVEL ARMS.
The most unfavourable load combination is taken as designed working condition of lifting pole to check strength of components, thus ensuring safety. The height of lifting pole (maximum independent height) is taken as main calculated working condition based on the rated lifting capacity.

During the lifting operation process of iron tower, the wind load borne by lifting pole is changing with the rising of lifting part. The finite difference method (with each subsection of $10 \mathrm{~m}$ ) is adopted to work out the maximum wind loads on the lifting pole applied by lifting part and steel wire rope. With the changing of wind direction as well as the rotating and amplitude changing of lifting pole, the wind load also changes constantly, so the maximum wind load should be worked out from different angles.

\section{Working CONDITION DESIGN Of Pole Body}

Composition of pole body: the pole body is $26.4 \mathrm{~m}$ in height, and the lower 5 sections are common sections of $1.09 \mathrm{~m}$, while the upper 3 sections are pole body sections of $0.9 \mathrm{~m}$. The cross-section characteristics of pole body are shown in Table I .

TABLE I .THE CROSS-SECTION CHARACTERISTIC OF POLE BODY
\begin{tabular}{|l|l|l|l|l|l|}
\hline $\begin{array}{l}\text { Main } \\
\text { chord } \\
\text { Cross- } \\
\text { section }\end{array}$ & $\begin{array}{l}\text { Area(c } \\
\left.\mathbf{m}^{2}\right)\end{array}$ & $\begin{array}{l}\text { Inertia } \\
\text { mome } \\
\mathbf{n t}\left(\mathbf{c m}^{4}\right. \\
\mathbf{)}\end{array}$ & $\begin{array}{l}\text { Rotary } \\
\text { radius( } \\
\mathbf{c m})\end{array}$ & $\begin{array}{l}\text { Slendern } \\
\text { ess ratio } \\
\lambda\end{array}$ & $\boldsymbol{\varphi}$ \\
\hline $\begin{array}{l}\square 110 \times 1 \\
10 \times 10, \\
\text { Q345B }\end{array}$ & 37.425 & 569.36 & 3.9 & 38.46 & 0.9025 \\
\hline
\end{tabular}




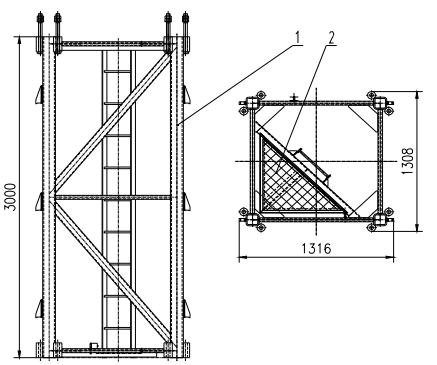

FIGURE II.STANDARD SECTION OF POLE BODY.

The sizes of standard section of pole body are shown in Table II .

TABLE II .THE SIZES OF STANDARD SECTION.

\begin{tabular}{|l|l|l|}
\hline Project & $\begin{array}{l}\text { Length }(\mathbf{m m}) \times \text { Width }(\mathbf{m m}) \times \\
\text { Height }(\mathbf{m m})\end{array}$ & Weight \\
\hline $\begin{array}{l}\text { standard sections } \\
\text { without rest } \\
\text { platform }\end{array}$ & $1316 \times 1308 \times 3000$ & 667.3 \\
\hline $\begin{array}{l}\text { standard sections } \\
\text { with rest platform }\end{array}$ & $1316 \times 1308 \times 3000$ & 682 \\
\hline
\end{tabular}

There are 32 standard sections without rest platform when lifting pole is $150 \mathrm{~m}$ (maximum working height). There is one standard section with rest platform each 3 standard sections without rest platform, and there are 16 standard sections with rest platform in $150 \mathrm{~m}$ pole.

In this thesis, the wind loads under different wind pressures should be calculated firstly.

Working condition 1: wind pressure is $250 \mathrm{~Pa}$, blown from lateral.

Working condition 2: wind pressure is $250 \mathrm{~Pa}$, blown from rear.

Working condition 3: wind pressure is $1100 \mathrm{~Pa}$ (abnormal), blown from lateral. Under this working condition, the lateral air blow is more dangerous than rear air blow, so it is only necessary to consider the lateral air blow.

The normal load factor is 1.0 , static load factor is 1.25 , and dynamic load factor is 1.1 .

\section{Wind LoAd CAlculation OF Pole Body}

The ANSYS is adopted to calculate the overall loadbearing of SP80 under rated lifting capacity[3]. In the simplified model, the load above top of pole body is converted to the pole body top. The calculated load-bearing situations of various components of pole body in working conditions 1,2 and 3 are as below:

\section{Working Condition 1}

(1) The calculation result of wind load/wind bending moment of pole top is shown in Table III.
TABLE III.CALCULATION RESULT OF WIND LOAD/WIND BENDING MOMENT OF POLE TOP.

\begin{tabular}{|l|l|l|}
\hline Project & $\begin{array}{l}\text { Wind load } \\
\text { (kg) }\end{array}$ & $\begin{array}{l}\text { Wind bending } \\
\text { moment (kg.m) }\end{array}$ \\
\hline Normal load & 1352.85 & 4974.84 \\
\hline Static load factor 1.25 & 1477.85 & 5351.09 \\
\hline $\begin{array}{l}\text { Dynamic load factor } \\
1.1\end{array}$ & 1402.85 & 5125.34 \\
\hline
\end{tabular}

(2)The load-bearing and stress of main chord in the lowest section ( $1.09 \mathrm{~m}$ section) of pole body is shown in TableIV.

TABLE IV. THE LOAD-BEARING AND STRESS.

\begin{tabular}{|l|l|l|l|}
\hline Project & $\begin{array}{l}\text { Normal } \\
\text { load }\end{array}$ & $\begin{array}{l}\text { Static } \\
\text { load }\end{array}$ & $\begin{array}{l}\text { Dynamic } \\
\text { load }\end{array}$ \\
\hline Bending moment (kg.m) & 40000 & 50000 & 44000 \\
\hline $\begin{array}{l}\text { Wind bending moment } \\
\text { (pole body root) (kg.m) }\end{array}$ & 40446.5 & 26460.15 & 41908 \\
\hline $\begin{array}{l}\text { Wind bending moment } \\
\text { (kg.m) }\end{array}$ & 10501.11 & 6300.67 & 10501.11 \\
\hline $\begin{array}{l}\text { Total wind bending } \\
\text { moment (pole body } \\
\text { root)(kg.m) }\end{array}$ & 50947.61 & 32760.82 & 52409.11 \\
\hline $\begin{array}{l}\text { Gross weight of upper } \\
\text { tower crane (kg) }\end{array}$ & 28479 & 30816.5 & 29414 \\
\hline $\begin{array}{l}\text { Main chord load-bearing } \\
\text { kg) }\end{array}$ & 48838.84 & 45667.8 & 51577.86 \\
\hline Main chord stress (MPa) & 144.6 & 135.21 & 152.71 \\
\hline
\end{tabular}

A. Working Condition 2

(1) The calculation result of wind load/wind bending moment of pole top is shown in Table $\mathrm{V}$.

TABLE V.CALCULATION RESULT OF WIND LOAD/WIND BENDING MOMENT OF POLE TOP.

\begin{tabular}{|l|l|l|}
\hline Project & $\begin{array}{l}\text { Wind load } \\
\text { (kg) }\end{array}$ & $\begin{array}{l}\text { Wind bending } \\
\text { moment (kg.m) }\end{array}$ \\
\hline Normal load & 884.05 & 3102.4 \\
\hline $\begin{array}{l}\text { Static load factor } \\
1.25\end{array}$ & 997.8 & 3444.31 \\
\hline $\begin{array}{l}\text { Dynamic load } \\
\text { factor 1.1 }\end{array}$ & 929.55 & 3239.15 \\
\hline
\end{tabular}

(2) The load-bearing and stress of main chord in the lowest section of pole body is shown in Table VI

TABLEVI.THE LOAD-BEARING AND STRESS.

\begin{tabular}{|l|l|l|l|l|l|l|}
\hline Project & \multicolumn{3}{|l|}{$\begin{array}{l}\text { The lowest section (0.9m } \\
\text { section) }\end{array}$} & \multicolumn{3}{|l|}{$\begin{array}{l}\text { The sixth section calculated } \\
\text { from the bottom (0.9m } \\
\text { section) }\end{array}$} \\
\cline { 2 - 7 } & $\begin{array}{l}\text { Norm- } \\
\text { al load }\end{array}$ & $\begin{array}{l}\text { Static } \\
\text { load }\end{array}$ & $\begin{array}{l}\text { Dyn- } \\
\text { amic } \\
\text { load }\end{array}$ & $\begin{array}{l}\text { Norm- } \\
\text { al load }\end{array}$ & $\begin{array}{l}\text { Static } \\
\text { load }\end{array}$ & $\begin{array}{l}\text { Dyn- } \\
\text { amic } \\
\text { load }\end{array}$ \\
\hline $\begin{array}{l}\text { Bending } \\
\text { moment } \\
\text { (kg.m) }\end{array}$ & 40000 & 50000 & 44000 & 40000 & 50000 & 44000 \\
\hline $\begin{array}{l}\text { Wind } \\
\text { bending } \\
\text { moment } \\
\text { (pole } \\
\text { body } \\
\text { root) } \\
\text { (kg.m) }\end{array}$ & 26282 & 17764 & 27612 & 13021 & 8783 & 13668 \\
\hline
\end{tabular}




\begin{tabular}{|l|l|l|l|l|l|l|}
\hline $\begin{array}{l}\text { Wind } \\
\text { bending } \\
\text { moment } \\
\text { (kg.m) }\end{array}$ & 14848 & 8909 & 14848 & 2259 & 1355 & 2259 \\
\hline $\begin{array}{l}\text { Total } \\
\text { wind } \\
\text { bending } \\
\text { moment( } \\
\text { pole body } \\
\text { root)(kg. } \\
\text { m) }\end{array}$ & 41130 & 26673 & 42460 & 15280 & 10139 & 15927 \\
\hline $\begin{array}{l}\text { Total } \\
\text { bending } \\
\text { moment( } \\
\text { pole body } \\
\text { root)(kg. } \\
\text { m) }\end{array}$ & 81130 & 76673 & 68860 & 55280 & 60139 & 59927 \\
\hline $\begin{array}{l}\text { Gross } \\
\text { weight of } \\
\text { upper } \\
\text { tower } \\
\text { crane } \\
\text { kg) }\end{array}$ & 28479 & 30816 & 29414 & 24629 & 26966 & 25564 \\
\hline $\begin{array}{l}\text { Main } \\
\text { chord } \\
\text { load- } \\
\text { bearing } \\
\text { kg) }\end{array}$ & 59759 & 57451 & 63450 & 49596 & 53998 & 53481 \\
\hline $\begin{array}{l}\text { Main } \\
\text { chord } \\
\text { stress } \\
\text { (MPa) }\end{array}$ & 176 & 170 & 187 & 146 & 159 & 158 \\
\hline (3) & & & & & & \\
\hline
\end{tabular}

(3) The calculation result of bolt strength is shown in TableVII.

TABLE VII. THE BOLT STRENGTH

\begin{tabular}{|c|c|c|c|c|}
\hline M30 Class 10.9 & $\begin{array}{l}\text { Norm } \\
\text { al } \\
\text { load }\end{array}$ & $\begin{array}{l}\text { Static } \\
\text { load }\end{array}$ & $\begin{array}{l}\text { Dyna } \\
\text { mic } \\
\text { load }\end{array}$ & $\begin{array}{l}\text { Allow } \\
\text { able } \\
\text { value }\end{array}$ \\
\hline $\begin{array}{l}\text { Tension force borne } \\
\text { by single bolt }(\mathrm{kg})\end{array}$ & $\begin{array}{l}22759 \\
.77\end{array}$ & 21021. & $\begin{array}{l}24371 \\
.93\end{array}$ & 7021 \\
\hline $\begin{array}{l}\text { Shear force borne by } \\
\text { single bolt }(\mathrm{kg})\end{array}$ & $\begin{array}{l}737.7 \\
4 \\
\end{array}$ & 611.53 & $\begin{array}{l}772.4 \\
7\end{array}$ & 3867 \\
\hline
\end{tabular}

Summary: Under working conditions 1 and 2, the height of tower crane is $26.4 \mathrm{~m}$, and the pole body consists of lower 5 common sections of $1.09 \mathrm{~m}$ and upper 3 standard sections of $0.9 \mathrm{~m}$, and pole body and bolt strength are all qualified.

B. Working Condition 3

(1) The load-bearing and stress of main chord of standard tower is shown in TableVIII.

TABLEVIII. CALCULATION OF MAIN CHORD LOAD-BEARING AND STRESS.

\begin{tabular}{|l|l|l|l|}
\hline Project & $\begin{array}{l}\text { The } \\
\text { lowest } \\
\text { section } \\
\mathbf{( 1 . 0 9 m} \\
\text { section) }\end{array}$ & $\begin{array}{l}\text { The third section } \\
\text { calculated from } \\
\text { the bottom } \mathbf{( 1 . 0 9 m} \\
\text { section) }\end{array}$ & $\begin{array}{l}\text { The sixth } \\
\text { section } \\
\text { calculated } \\
\text { from the } \\
\text { bottom } \\
\mathbf{0 . 9 m} \\
\text { section) }\end{array}$ \\
\hline $\begin{array}{l}\text { Bending moment } \\
\text { of pole top (kg.m) }\end{array}$ & 0 & 0 & 0 \\
\hline $\begin{array}{l}\text { Wind bending } \\
\text { moment of pole top } \\
\text { (pole body root) } \\
\text { (kg.m) }\end{array}$ & 177964.62 & 142249.44 & 88676.67 \\
\hline
\end{tabular}

\begin{tabular}{|l|l|l|l|}
\hline $\begin{array}{l}\text { Wind bending } \\
\text { moment of pole } \\
\text { body (kg.m) }\end{array}$ & 65333.71 & 39186.93 & 12425.53 \\
\hline $\begin{array}{l}\text { Total wind bending } \\
\text { moment of pole } \\
\text { body root (kg.m) }\end{array}$ & 243298.32 & 181436.37 & 101102.2 \\
\hline $\begin{array}{l}\text { Total bending } \\
\text { moment of pole } \\
\text { body root (kg.m) }\end{array}$ & 243298.32 & 181436.37 & 101102.2 \\
\hline $\begin{array}{l}\text { Gross weight of } \\
\text { upper tower crane } \\
\text { (kg) }\end{array}$ & 19129 & 17589 & 15279 \\
\hline $\begin{array}{l}\text { Main chord load- } \\
\text { bearing (kg) }\end{array}$ & 162639.02 & 122116.76 & 83265.14 \\
\hline $\begin{array}{l}\text { Main chord stress } \\
\text { (MPa) }\end{array}$ & $\begin{array}{l}481.52 \\
\text { (unqualifie } \\
\text { d) }\end{array}$ & $\begin{array}{l}361.55 \\
\text { (unqualified) }\end{array}$ & $\begin{array}{l}246.52 \\
\text { (unqualifie } \\
\text { d) }\end{array}$ \\
\hline
\end{tabular}

(2) The calculation of hawser cable is shown in TableIX. The angle between hawser cable and ground is $80^{\circ}$.

\section{TABLEIX.THE THIRD SECTION (1.09M SECTION) FROM THE} BOTTOM.

\begin{tabular}{|l|l|l|}
\hline Bending moment of pole top (kg.m) & \multicolumn{2}{l|}{0} \\
\hline $\begin{array}{l}\text { Total wind bending moment of pole body } \\
\text { root (kg.m) }\end{array}$ & \multicolumn{2}{|l|}{181436} \\
\hline Horizontal force of hawser cable $(\mathrm{kg})$ & 7000 & 4000 \\
\hline $\begin{array}{l}\text { Bending moment generated by horizontal } \\
\text { force of hawser cable (kg.m) }\end{array}$ & $\begin{array}{l}\text { (851 } \\
50\end{array}$ & $\begin{array}{l}1058 \\
00\end{array}$ \\
\hline Vertical force of hawser cable $(\mathrm{kg})$ & 3969 & 2268 \\
\hline $\begin{array}{l}\text { Total bending moment of pole body root } \\
\text { (kg.m) }\end{array}$ & - & $\begin{array}{l}7563 \\
6\end{array}$ \\
\hline Gross weight of upper tower crane $(\mathrm{kg})$ & 1758 & 1758 \\
\hline Main chord load-bearing (kg) & 9 & 9 \\
\hline Main chord stress (MPa) & 9 & 5914 \\
\hline
\end{tabular}

(3) The calculation result of bolt strength (M30 Class 10.9) is shown in Table X.

\section{TABLE X.THE BOLT STRENGTH}

\begin{tabular}{|l|l|l|l|}
\hline Bolt M30 Class 10.9 & $\begin{array}{l}\text { Theoretica } \\
\text { l value }\end{array}$ & $\begin{array}{l}\text { Allowable } \\
\text { value }\end{array}$ & Remark \\
\hline $\begin{array}{l}\text { Tension force borne by } \\
\text { single bolt }(\mathrm{kg})\end{array}$ & 19503.56 & 27021 & Qualified \\
\hline $\begin{array}{l}\text { Shear force borne by } \\
\text { single bolt }(\mathrm{kg})\end{array}$ & 2734 & 8635.5 & Qualified \\
\hline
\end{tabular}

Summary: Under working condition 3, the height of tower crane is $26.4 \mathrm{~m}$, and the main chord stress of pole body exceeds allowable value in case that there is no hawser cable, so it is necessary to reduce two $1.09 \mathrm{~m}$ sections and then add hawser cable, with the horizontal force borne by hawser cable of $4 \mathrm{t}-7 \mathrm{t}$. At this time, the main chord stress should be within the allowable scope.

In a word, the pole body structure meets stability requirements.

\section{CONCLUSION}

Through analysing the wind load borne by pole body of landing-type lifting pole with double-level arms, this thesis proposed wind load conditions under different wind pressures and wind directions, and has judged the safety and stability of 
pole body and bolt strength according to calculated loadbearing situations of various components of pole body under working conditions 1,2 and 3 .

\section{REFERENCES}

[1] Q.J.Li, G.L.Lin, H.X.Liu. Application of double horizontal rotating and lifting arm grounding hold-poles in construction of large crossing towers.Guangdong Electric Power, 11(1), pp. 72-76, 2011.

[2] J.Y. Ye, C.S.Huang, F.P.Duan. A structure pattern of derrick with double level arm rotating pole and Application. Engineering and Construction.23(3), pp.399-401, 2009.

[3] J.Z.Bai, Q.Sun, Y.N.Guo, Stress-analysis of a complex structure with the ANASYS system, Mechanical Science and Technology. 22(3), pp. 441$444,2003$. 